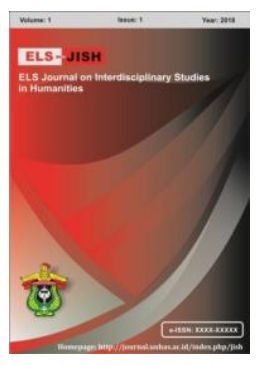

ELS-JISH

ELS Journal on Interdisciplinary Studies on Humanities

Volume 3 Issue 3, 2020

ISSN (print) : 2621-0843

ISSN (online) : 2621-0835

Homepage : http://journal.unhas.ac.id/index.php/jish

\title{
Ornaments as a Tourist Attraction at the King Binamu Tomb Complex in Bontoramba District, Jeneponto Regency
}

\author{
Damar Tri Afrianto'
}

damar.tria@gmail.com

\begin{abstract}
The existence of ornament which adorns almost the entire walls of the tomb functions as decorative or symbolic. Ornamen provided information about the life of Raja Binamu when he was still victorious. The analysis is described in a descriptive qualitative manner with an interpretive approach. The discussion is described based on problems related to how the ornament is able to be an attraction of visitors or tourists. The scavenger began by analyzing the ornament in the tomb with Thomas Murno's ornamental composition theory which was developed in Guntur, according to Murno, organizing the composition in art works in this case there were four models of ornaments, namely: composition based on expediency, composition based on representation, composition based on expository, and thematic based composition. It also uses concepts that are based on tourism science strategies. The results obtained in the form of an understanding that the ornaments there contain two understandings, namely ornamentation as a decorative element, namely the presence of thematic repetition ornaments such as parengreng flower motifs. The symbolic ornaments explain the life and activities of kings during his life and have a moral message. Related to its potential as a tourist attraction, the presence of ornaments needs an understanding and image strategy in the form of 1) bringing up ornaments or ornaments in each of the promotional media, 2) providing information about the types of decoration or ornaments in books (booklets) tourist guides and 3 ) creating merchandise taken from ornamental motifs in the Raja Binamu tomb complex.
\end{abstract}

Keywords: Ornament, Raja Binamu Tomb Complex, Tourist Attraction.

How to cite: Afrianto, T. D. (2020). Ornaments as a Tourist Attraction at the King Binamu Tomb Complex in Bontoramba District, Jeneponto Regency. ELS Journal on Interdisciplinary Studies in Humanities, 3(3), 366-375. DOI: https://doi.org/10.34050/elsjish.v3i3.11012

\section{Introduction}

Indonesian culture has never stopped traces of cultural expressions that have charm and the values contained therein. The legacy of the expression of cultural expression is proof that civilization in the past keeps the events that followed. Ornament is a form of cultural expression that stores events and experiences in the past. Ornament is one type of cultural expression that cannot be separated from elements of local wisdom and a reflection of local culture. This is also explained by Guntur (2004: 4) that ornament is an expression of people's ideas, attitudes, and behavior. Besides that, ornaments also carry 
social, moral, religious and even political messages. Ornaments as a form of cultural product have provided a beautiful and aesthetic appearance to an object so that it can increase respect for that object, both spiritually and materially. In addition, the ornament affixed to a product has symbolic value or contains certain messages.

The King Binamu Tomb Complex in Bontoramba District, Jeneponto Regency, has an interesting charm, namely the presence of ornaments that adorn almost the vicinity of the Tomb. King Binamu's funeral complex not only provides information about the heroism of the kings who once ruled, but the ornaments attached to the tomb also provide information about the life of the Binamu kings. In general, the existence of the tombs of the Binamu kings was the final resting place and a sign of I The ornaments attached to the tombs have different decorations in each tomb. The types of ornaments found in the tomb include flora ornaments such as lotus flowers, parengreng flowers (tendrils), tanri flowers, and fauna motifs such as lions, chickens and horses, as well as several motifs from human stylization. Ornamental motifs are scattered in several tomb complexes.egitimacy for a kingdom, in this case the Binamu Kingdom.

there have been known pre-Islamic burial systems performed by ethnic groups in South Sulawesi, prior to the influence of Islamic and European cultures (Duli, 2018). The burial complex of the Binamu kings is historical evidence that Jeneponto once had a large kingdom in South Sulawesi. There are 1250 tombs consisting of the king and his descendants. The large number of tombs accompanied by beautiful ornaments on each side of the tomb attracts the public to take a closer look at the tombs of King Binamu. This place is often visited by students from elementary to secondary level for historical studies and also some students from universities to do research. The ornaments adorning King Binamu's tombs represent a certain past achievement, which is worthy of admiration. Digging deeper into the presence of ornament is able to reveal the realities of the lamp age as a source of inspiration for the future. The presence of the ornament attaches the uniqueness of the Tomb of the Kings of Binamu among other tomb complexes so that it becomes an alternative place for amazing monuments that are important to visit as historical tourism.

Through this understanding, it is necessary to observe and analyze the analysis related to the potential ornaments in the tomb of the Kings of Binamu as an attraction for visitors, especially local and international tourists. This research examines the role of ornament as a medium of historical tourism attraction in the Raja Binamu complex in the district, Bontoramba, Kab. Jeneponto.

Based on the background above, the problems can be formulated including; how the shape and function of the ornaments in the tomb complex of King Binamu and how the roles of the ornaments as a medium of tourist attraction in the tomb complex of King Binamu. 


\section{Method}

\subsection{Interaction Analysis}

Analysis with the interaction analysis approach is to obtain qualitative information by applying a cycle system. The cycle system refers to Miles and Huberman (1992: 19) starting from data reduction, data presentation, and drawing conclusions. Data reduction is defined as the process of selecting, focusing attention on simplifying, abstracting, and transforming "rough" data that emerge from written records in the field. After the data reduction process, the next step is to present the data, namely a set of information structures that give the possibility of drawing conclusions and taking action. By looking at data presentations one can understand what is happening and what must be done, further analyze or take actions based on the understanding obtained from these presentations. The next analysis activity is to draw conclusions or verification. The verification stage begins to record regularities, patterns, explanations, configurations, and proportions (Miles and Haberman, 1992: 16-19).

The process of data analysis with an interaction model from the beginning of data collection, data reduction, and data presentation has the nature of intertwining moving and acting as objects during the research process. This model was chosen because it allows for more single records that are capable of capturing input and exposure in a summary that is data reduction and inference.

\subsection{Analysis Interpretation}

Interpretation analysis method is a method of analysis that uses theory as a guide in describing the reality of research. The theory used in this study uses two theoretical perspectives, namely the theory related to decoration or ornamentation and the concept of tourist attraction. Theories related to decoration are used to analyze. ornamental object in the Tomb of King Binamu. Meanwhile, the theory of tourist attraction is used to reveal ornaments as a medium in supporting historical tourism in the tomb complex of the Binamu Kings.

The theory from the perspective of decoration or ornamentation uses the theory of Thomas Murno developed in Guntur, according to Murno, there are four models of organizing compositions in works of art, namely: composition based on benefits, composition based on representation, composition based on expository, and composition thematic based.

Composition benefit is achieved through the arrangement of the parts in a certain way as an instrument for its active purpose or use. Uses. Meanwhile, representative composition is an arrangement of parts as a way to present a concrete imagination of an object. Representation in this case is divided into two, namely mimetic or imitative representation and symbolic representation. Furthermore, the composition of the expository is the arrangement of parts to organize general relations, such as a causal relationship or logical relationshipabstract meaning, pervasive quality, general principles or basic rules. The last composition is thematic composition, or 'design', which is a way of organizing works through repetition, variation, contrast, and integration of certain characteristics or characters (Guntur, 2004: 130). 


\section{Findings and Discussion}

\subsection{Scope and Overview of Oranamen in the Binamu Kings Complex}

As is known, tourism objects are not only in the form of natural exoticism and unique products in an area, but historical issues have relevance for tourism deposits. Tourism objects in the form of historical aspects through their legacy can attract admiration and can enrich visitors' insights and experiences. In addition to storing historical information, the King Binamu tomb complex in Jenekponto has a unique view, namely the presence of beautiful ornaments around the tomb. Soepratno (1997: 11) explains the meaning of ornament. According to him, ornament comes from the Greek word ornare which means decoration or jewelry. The decoration or ornament itself consists of various types of motifs. The motifs are used to decorate something we want to decorate. Therefore, the motif is the basis for decorating an ornament. Ornaments are intended to decorate a field or object, so that the object becomes beautiful as we see in the decoration of book skins, certificates, batik cloth, flower holders and other items. Furthermore, Guntur (2004: 53) explains that ornament is an art that uses decorative elements (motifs) as a medium of expression to beautify something, both two-dimensional and three-dimensional. Ornaments, thus, are part of the universal elements of culture which are included in the realm of art.

The need for decoration or ornamental activities in Indonesia has been going on for a long time. According to Van Der Hoop, the need for decoration appears in the dong-soon or bronze culture. At that time, ornamental forms or oranamen were found in the form of "S" or multiple twists, swastikas and meanders (1949: 13). The acquaintance with decorations over a long period of time has certainly become a culture. Ornament is no longer a side activity but is an expression of culture that has scratched and has a specific purpose and purpose. As mentioned in the introductory sub-introduction, ornaments do not just stick to the tomb, but the meaning requirements are stored behind them. The basic concept of ornament is to decorate something to make it more beautiful. The oldest civilization manifestation (pre-history) shows the important role of ornament in various cultural products. Past and present artifacts cannot be separated from the services of ornament (Guntur, 2004: 15) through this understanding that it is clear that an arrangement is not sufficient to only be conceptualized as an activity to beautify objects, but there is information about the past and the motivation for the formation of ornament.

In addition to pragmatic interests as the final resting place, the Tomb of the Kings of Binamu in Jeneponto, ornamentation has another importance as a medium for reading information related to the lives of the binamu kings. Like one of the tombs in the tomb complex, namely the tomb of King Karaeng Palangkei Daeng Lagu who was also the first king of Binamu (Interview with Supardi, 28 May 2016). According to Supardi's explanation, Karaeng Palangkei Lagu was known to a king who liked fighting, cock, the king had very high strength because he was able to fight against a large number of his enemies.

The greatness and strength of the King of Karaeng Palangkei Daeng Lagu is reflected in the ornaments attached to his tomb. The ornaments in the king's 
tomb have many motifs among the motifs in other tombs. The ornamental motifs range from fauna motifs in the form of tigers at the top of the tomb, to horse, chicken, dog motifs and flora motifs such as running flower ornaments, and some also have geometric motifs such as spirals.

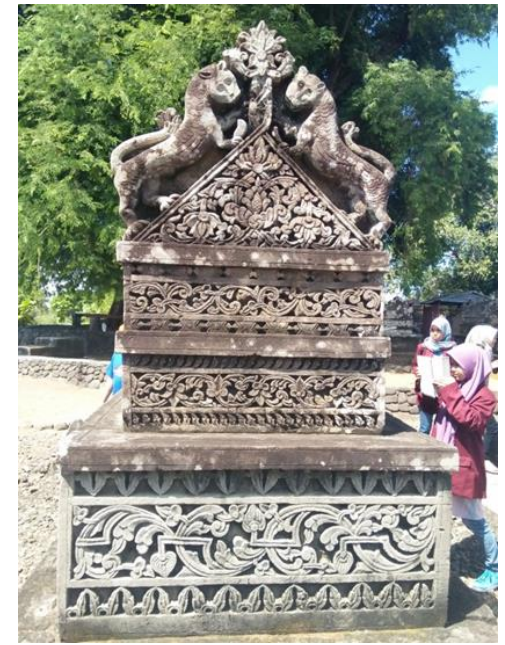

Figure 1. Tomb of King Karaeng Palangkei Daeng Song

The ornamental composition at the Tomb of the King of Karaeng Palangkei Daeng Lagu was composed based on the aspee of benefit. The composition of the benefits of the ornament in this case has the benefit of general information about the greatness of Raja Karaeng Palangkei Daeng Lagu. This can be seen in the composition of large size ornaments such as tigers, as well as dense ornaments on each side of the tomb. The composition provided the benefit of building a strong image of the king's greatness.

The representative composition of the ornaments at the tomb of Raja Palangkei Daeng Lagu also has two representatives, namely mimetic and symbolic. Mimetic representations are present in a number of floral motifs in the form of parenreng flowers in the center of the tomb. This parengreng flower motif is a form of imitation of the parengreng flower that spreads continuously.

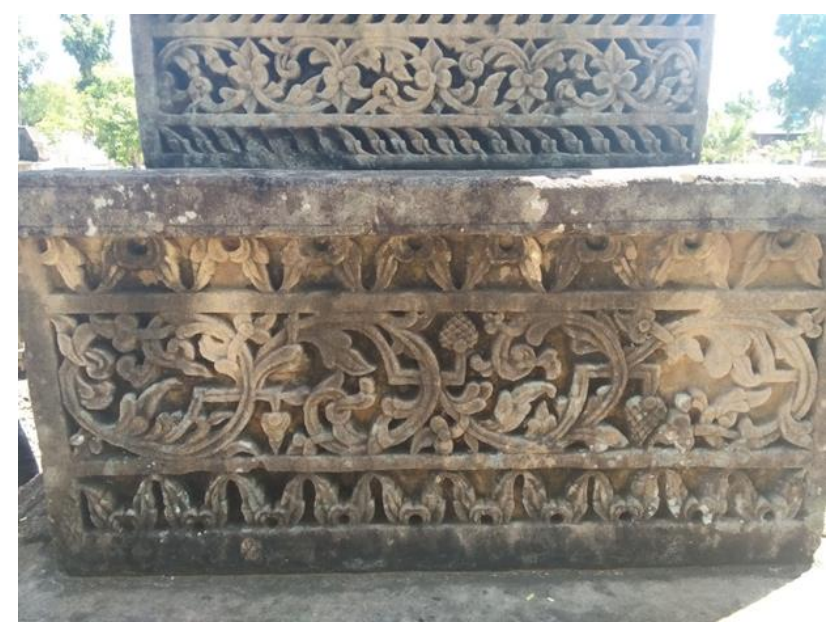

Figure 2. Ornament with Composition of Parengreng Flower Mimetic Representation 
Symbolic representations are present with many symbols in the tomb of Raja Raja Palangkei Daeng Lagu. The symbols that appear include the chicken motif on the first panel. The fauna motif depicting a chicken is a symbolic representation of the activities of King Palangkei Daeng Lagu, who during his lifetime loved to fight chickens.

In addition to the chicken motif, there is also a human depiction motif using a complete shot on the second panel, this is a symbolic representation that Raja Palangkei Daeng Lagu is a feared warrior who is skilled in using war equipment. In the third panel there is a motif depicting a man with a horse, this is a symbolic representation that in leading the kingdom and during the war, King Palangkei Daeng used a horse as his vehicle.

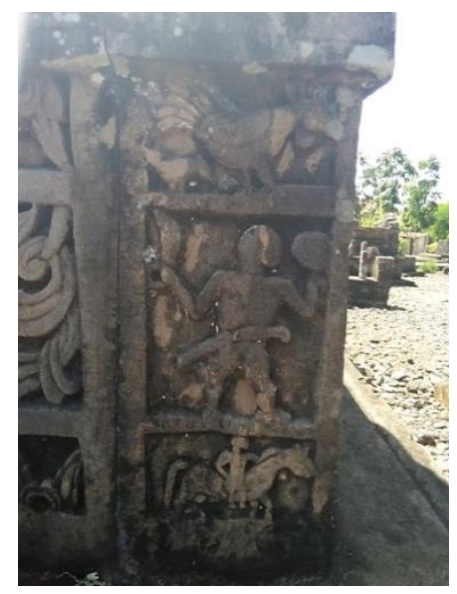

Figure 3. Ornament Panel with a Composition of Symbolic Representations in the Form of a Chicken Motif, an Armed Man and a Depiction of a Man with a Horse.

The expository composition of the tomb of King Palangkei Daeng Lagu can be seen in the fauna motif, namely the tiger on the top side of the tomb. The tiger in the tomb is composed for a causal relationship or an abstract logical-meaning relationship, namely conveying ideas about courage. The tiger in the conception of the people of South Sulawesi is called "macan Kebo" which means the name for the front leader in defending his kingdom, in this case Raja Palangkei Daeng Lagu.

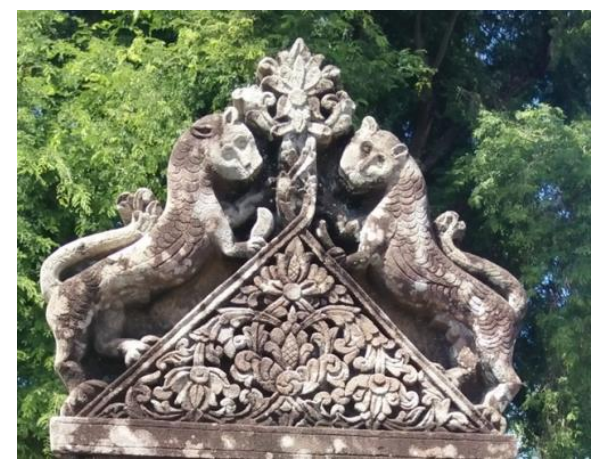

Figure 4. The Motif of Macan Kebo' Ornament which is an Expository Composition 
The 'macan kebo' motif which stands firmly on the grave parallel to the face facing forward, there is also a floral motif of parengreng with a triangular frame. This tiger ornament is the center of attention in the tomb complex of King Binamu. Tiger ornaments are only found in the tomb of King Palangkei Daeng Lagu. This tomb is always the first to be visited by tourists among other graves. In addition to the dense and unique ornamentation of the other tombs, this tomb also has Arabic and lontara writing on it.

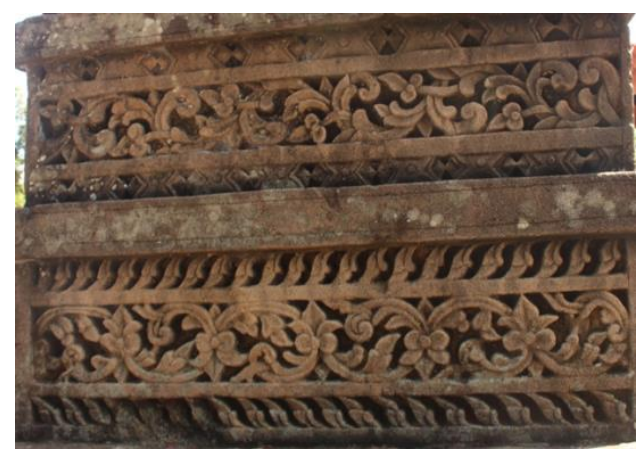

Figure 5. Repetition Thematic Motives

The next composition is related to the composition which is theatic. This thematic composition in the tombs of the kings of your son is mostly found in geometric motifs, and some are also found in naturalist motifs. The first thematic is repetition composition. This composition requires repeated depiction. Almost all tombs in the tomb complex of King Binamu have panrenreng flower motifs arranged in a repetitive manner.

Next, it is thematic for compositions based on variations. Variation composition entails differences between details, parts, qualities, or events. Thematic variations, as well as thematic repetitions, are constructed by floral motifs (parenreng flowers) and combined by geometric motifs.

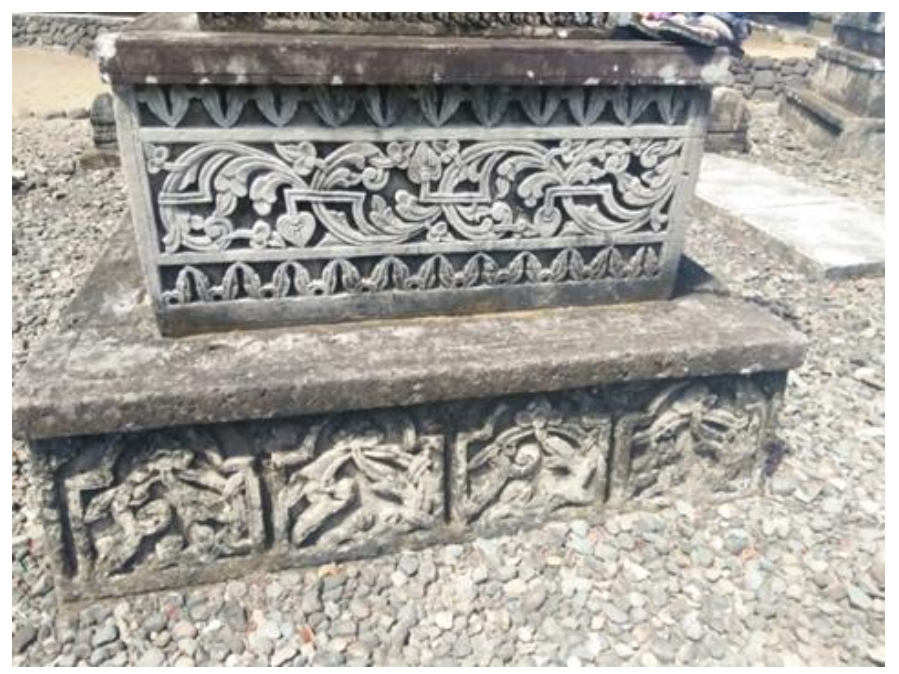

Figure 6. Motifs with Thematic Variations of Geometric and Naturalists

The next thematic is contrast thematic. Contrast thematic entails larger or smaller differences as well as stark differences between details, parts, quality, or events. In the tomb complex of King Binamu, a contrasting thematic 
composition is found, namely the combination of two different motive elements from spiral geometric motifs with human depiction motifs in the image below.

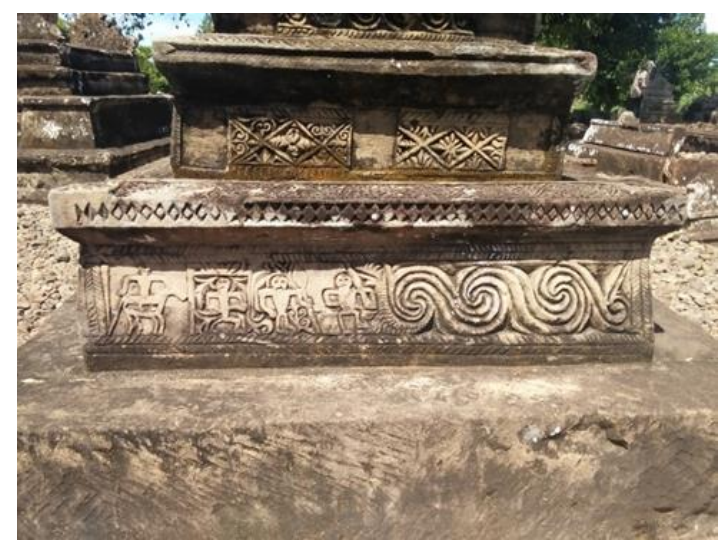

Figure 7. Contrast Thematic Motifs

The analysis of the ornaments above shows that ornaments are not just attached to a tomb decoration. However, more than that the ornament has information about the life of the king who was buried there. As well as the various forms and variations of ornaments that are present provide an understanding of the variety of decorations that developed at that time.

\subsection{Ornaments as a Tourist Attraction}

A person's decision to take a tour is influenced by the strength of the push factors and the pull factors (Pitana \& Gayatri, 2005: 66). Of course, many factors motivate travel. The dominant factor is usually escape, which means wanting to escape from an environment that feels boring or simply wanting to relax. However, further development, travel does not only lead to this aspect, but also penetrates into knowledge or education tours.

The Binamu Kings Tomb Complex in Jeneponto certainly has great potential as a tourist attraction based on knowledge and history. History takes center stage in this destination. But on the other hand, apart from historical aspects, the decorations or ornaments attached to the tombs are able to increase tourist attraction. Of course, there is not much awareness about ornament as a tourist attraction. One of the charms of the public wanting to visit the tomb complex of King Binamu is the presence of ornaments. However, the tour guide does not convey the understanding of ornaments and the ornaments are not appointed as the image of the King Binamu tomb complex.

The tomb complex of King Binamu in Jeneponto doesn't know much about its existence specifically to make it a tourist destination. Its presence is still limited as a place to visit elementary to middle school students for historical studies. In fact, ornamental and historical beauty has great potential as a tourist attraction. For that we need an image of a tourist destination through the potential in this case ornament. Ornaments with all decorative aspects and beauty when imaged in the right method can become a tourist attraction. This is also explained by Pitana and Gayatri (2005: 65) that images can also give the 
impression that a destination provides an attraction that is different from other destinations, thereby increasing the desire to visit a destination.

Seeing the lack of tourist attraction to the King Binamu Tomb Complex, this paper tries to propose an image strategy using exotic ornaments that have been discussed in the initial section. The ideas put forward include 1) bringing up decorations or ornaments in every promotional media, meaning that at this time the Binamu Kings complex in Jeneponto is only known as a tomb and historical tourism, but not many people know that the tomb is rich in beautiful ornaments and holds past information. 2) provide information about the types of decorations or ornaments in the travel guide booklet, so that when tourists visit the destination, they do not only capture photos of the ornaments but understand explanations through books or booklets. 3) creating merchandise taken from ornamental motifs in the tomb complex of King Binamu. Merchandise can be in the form of product variations, from key chains, miniatures, or replicas and so on. This is one strategy to introduce ornaments or decorations to tourists. Through the understanding and ideas offered through this strategy, it is hoped that the ornament will be able to support the image of a tourist destination besides the historical aspects that exist in the tomb complex of King Binamu in Jeneponto

\section{Conclusion}

The artifacts of the past and also the present cannot be separated from ornament services. Oranamen or decorative styles have taken root in Indonesian society. Events and lives in the past can be read through ornaments. Apart from being a medium for reading past events, ornaments offer a beauty that is suggestive of nature. In connection with this, the ornament must be studied more deeply because it has great potential, especially in the tourism sector.

The tomb complex of King Binamu in Jeneponto, South Sulawesi, apart from being a historical place, also has exotic ornaments inherent in almost all tombs. This beauty does not spoil the eyes, but also provides knowledge and insight related to past lives, especially the triumph of the kings of Binamu who were brave and tough in defending their kingdom.

Through analysis related to ornaments at the Tomb of the Kings of Binamu, it can be concluded that the ornament contains two understandings, namely ornament as a decorative element, namely by the presence of repetitive thematic ornaments such as parengreng flower motifs. Apart from being a decorative ornament in the tomb, it is also symbolic, this is with the faunal motifs such as; chickens, horses, tigers and human description motifs. The symbolic ornament describes the life and activities of the kings during their lifetime and has a moral message.

In relation to its potential as a tourist attraction, the presence of ornaments requires understanding and image strategies in the form of 1) bringing up decorations or ornaments in each promotional media, 2) providing information about the types of decorations or ornaments in the travel guide booklet and 3 ) created merchandise taken from ornamental motifs in the tomb complex of King Binamu. 
Through understanding ornament as decorative and symbolic work and tourism image strategy, it is hoped that the King Binamu tomb complex will become an alternative strategic tourist destination for tourism-based, art, history and education. Efforts to make this happen require the attention of all parties, including government, society and academia. As it is known, tourism which is based on history, education and culture has received less attention than tourism based on natural beauty.

\section{References}

Duli, A., \& Rosmawati, R. (2018). Late Prehistoric Burial System in South Sulawesi. ELS Journal on Interdisciplinary Studies in Humanities, 1(2), 134-144. https://doi.org/10.34050/els-jish.v1i2.4371

Guntur. (2004). Ornamen Sebuah Pengantar. Surakarta: STSI Surakarta Press.

Hoop. V. D. (1949). Indonesian Ornamenal Design. Batavia, Koninklijk Bataviaasch Genootschap van Kunsten en Wetenschappen.

Miles, M. B. \& Huberman, A.M. (1992). Analisis Data Kualitatif. Terj. Tjetjep Rohendi Rohidi. Jakarta: Universitas Indonesia, UI Press.

Pitana, I G. \& Gayatri, P.G. (2005). Sosiologi Pariwisata. Yogyakarta: Penerbi Andi.

Rohidi, T.R. (2011). Metodologi Penelitian Seni. Semarang: Cipta Prima Nusantara

Soepratno. (1997). Ornamen Ukir Tradisional Jawa II. Semarang: IKIP Semarang Press.

Suryadana, M. L.\& Octavia, V. (2015). Pengantar Pemasaran Pariwisata. Bandung: Alfabeta 